\title{
Developmental up-regulation of NMDA receptors in the prefrontal cortex and hippocampus of mGlu5 receptor knock-out mice
}

\author{
Tiziana Imbriglio ${ }^{1 \dagger}$, Remy Verhaeghe ${ }^{1 \dagger}$, Nico Antenucci ${ }^{2}$, Stefania Maccari2, ${ }^{2,3}$, Giuseppe Battaglia ${ }^{1,2}$,
} Ferdinando Nicoletti ${ }^{1,2^{*}}$ (D) and Milena Cannella ${ }^{1}$

\begin{abstract}
mGlu5 metabotropic glutamate receptors are highly expressed and functional in the early postnatal life, and are known to positively modulate NMDA receptor function. Here, we examined the expression of NMDA receptor subunits and interneuron-related genes in the prefrontal cortex and hippocampus of $\mathrm{mGlu}^{-1-}$ mice and wild-type littermates at three developmental time points (PND9, -21 , and -75 ). We were surprised to find that expression of all NMDA receptor subunits was greatly enhanced in $\mathrm{MGlu}^{-1-}$ mice at PND21. In contrast, at PND9, expression of the GluN2B subunit was enhanced, whereas expression of GluN2A and GluN2D subunits was reduced in both regions. These modifications were transient and disappeared in the adult life (PND75). Changes in the transcripts of interneuron-related genes (encoding parvalbumin, somatostatin, vasoactive intestinal peptide, reelin, and the two isoforms of glutamate decarboxylase) were also observed in $\mathrm{GGlu}^{-/-}$mice across postnatal development. For example, the transcript encoding parvalbumin was up-regulated in the prefrontal cortex of mGlu5 $5^{-1}$ mice at PND9 and PND21, whereas it was significantly reduced at PND75. These findings suggest that in $\mathrm{mGlu}^{-/}$- mice a transient overexpression of NMDA receptor subunits may compensate for the lack of the NMDA receptor partner, mGlu5. Interestingly, in $\mathrm{mGlu}^{-1-}$ mice the behavioral response to the NMDA channel blocker, MK-801, was significantly increased at PND21, and largely reduced at PND75. The impact of adaptive changes in the expression of NMDA receptor subunits should be taken into account when $\mathrm{mGlu}^{-/-}$mice are used for developmental studies.
\end{abstract}

Keywords: Interneuron related genes, NMDA receptor subunits, Prefrontal cortex, Hippocampus MK-801, Locomotor activity

\section{Introduction}

One of the earliest discovery in the field of metabotropic glutamate (mGlu) receptors was that glutamatestimulated polyphosphoinositide (PI) hydrolysis was

\footnotetext{
*Correspondence: ferdinandonicoletti@hotmail.com

†Tiziana Imbriglio and Remy Verhaeghe equally contributed to this work.

${ }^{2}$ Department of Physiology and Pharmacology "V. Erspamer", University

Sapienza of Rome, Piazzale Aldo Moro, 5, 00185 Rome, Italy

Full list of author information is available at the end of the article
}

prominent in the first 9-10 days of postnatal life, and then progressively declined to become negligible in the adult life [1]. Subsequent studies have shown that the large PI response to glutamate early after birth was mediated by the mGlu 5 receptor, one of the two receptor subtypes coupled to $\mathrm{G}_{\mathrm{q} / 11}[2,3]$. mGlu5 receptors are highly expressed in the early postnatal life in most of the forebrain regions, and expression declines afterwards $[4,5]$ with a developmental shift from mGlu5a to mGlu5b splice variants in the cerebral cortex,

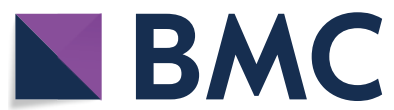

(c) The Author(s) 2021, corrected publication 2021 Open Access This article is licensed under a Creative Commons Attribution 4.0 International License, which permits use, sharing, adaptation, distribution and reproduction in any medium or format, as long as you give appropriate credit to the original author(s) and the source, provide a link to the Creative Commons licence, and indicate if changes were made. The images or other third party material in this article are included in the article's Creative Commons licence, unless indicated otherwise in a credit line to the material. If material is not included in the article's Creative Commons licence and your intended use is not permitted by statutory regulation or exceeds the permitted use, you will need to obtain permission directly from the copyright holder. To view a copy of this licence, visit http://creativecommons.org/licenses/by/4.0/. The Creative Commons Public Domain Dedication waiver (http:/creativecommons.org/publicdomain/zero/1.0/) applies to the data made available in this article, unless otherwise stated in a credit line to the data. 
Table 1 Primer sequences used for real-time PCR analysis

\begin{tabular}{|c|c|c|}
\hline Name & Primer & Seq $5^{\prime}->3^{\prime}$ \\
\hline \multirow[t]{2}{*}{ Gad1 (GAD67) } & Forw & GTACTCCTGTGACAGAGCCG \\
\hline & Rev & GTATTAGGATCCGCTCCCGC \\
\hline \multirow[t]{2}{*}{ Gad2 (GAD65) } & Forw & GAGCTGCAGCCTTAGGGATT \\
\hline & Rev & GCACTCACCAGGAAAGGAAC \\
\hline \multirow[t]{2}{*}{ Grin1 (GluN1) } & Forw & AACCTGCAGCAGTACCATCC \\
\hline & Rev & GCAGCAGGACTCATCAGTGT \\
\hline \multirow[t]{2}{*}{ Grin2A(GluN2A) } & Forw & TCTCCGCCTTTCCGATTTGG \\
\hline & Rev & TGGCAAAGATGTACCCGCTC \\
\hline \multirow[t]{2}{*}{ Grin2B (GluN2B) } & Forw & CGCTCTCCACACCCTGAGAT \\
\hline & Rev & TAGAAGCCAAAGCTCTAGGC \\
\hline \multirow[t]{2}{*}{ Grin2C (GluN2C) } & Forw & CATTAGGGATTTCCCCAAACGC \\
\hline & Rev & ACCTTCCTAGTCCAAGCACA \\
\hline \multirow[t]{2}{*}{ Grin2D (GluN2D) } & Forw & TCCTGGGGGACGATGAGATT \\
\hline & Rev & AGTCGCCAGTACACAAGGTG \\
\hline \multirow[t]{2}{*}{ Pvalb (parvalbumin) } & Forw & GCTTCTCCTCAGATGCCAGA \\
\hline & Rev & CCACTTAGCTTTCAGCCACC \\
\hline \multirow[t]{2}{*}{ Reln (reelin) } & Forw & CTCGACAAGCATCCAGTCTTC \\
\hline & Rev & AGGTTGGTTGTAGGCAGGTG \\
\hline \multirow[t]{2}{*}{ Sst (somatostatin) } & Forw & CCCAGACTCCGTCAGTTTCT \\
\hline & Rev & CCAGGGCATCATTCTCTGTC \\
\hline \multirow[t]{2}{*}{ Tfrc (transferrin receptor) } & Forw & CCAGTGTGGGAACAGGTCTT \\
\hline & Rev & GCACCAACAGCTCCAAAGTC \\
\hline \multirow{2}{*}{$\begin{array}{l}\text { Vip (vasoactive intestinal } \\
\text { peptide) }\end{array}$} & Forw & GGAGCAGTGAGGGAGATTCTG \\
\hline & Rev & CGTGGTTGTTTTCCTTCGAG \\
\hline
\end{tabular}

hippocampus and corpus striatum [6]. This evidence suggests that mGlu5 receptors are involved in mechanisms that shape the developmental trajectory of the CNS in the postnatal life. Of note, mGlu 5 receptors are drug candidate targets for the treatment of neurodevelopmental disorders, such as monogenic autism and schizophrenia [7-15]. mGlu5 receptors are expressed on cortical and hippocampal GABAergic interneurons, which coordinate network oscillations and feedback/ feedforward inhibition mechanisms [16, 17]. Genetic deletion of mGlu5 receptors causes alterations in the expression of interneuron-related genes in the prefrontal/frontal cortex and hippocampus of adult mice [18], and disrupted latent inhibition [19]. In addition, postnatal ablation of mGlu5 receptors from parvalbumin (PV)-positive interneurons caused a schizophrenia-like phenotype in adult mice, characterized by impaired rhythmic cortical oscillatory activity and alterations in sensory-motor gating, learning and memory, and social recognition [20].

Little is known on how the absence of mGlu 5 receptors affects the biology of interneurons across postnatal development. We have found recently that the density of perineuronal nets (PNNs), which are specialized formations of the extracellular matrix surrounding parvalbuminpositive $\left(\mathrm{PV}^{+}\right)$interneurons, was largely increased in the somatosensory cortex of mice lacking mGlu5 receptors at PND16 [21], suggesting a role for mGlu5 receptors in mechanisms of developmental plasticity of cortical interneurons.

Here, we examined the expression of biochemical makers of GABAergic interneurons in the prefrontal cortex and hippocampus of mGlu5 receptor knockout mice at three time points of postnatal development (PND9, PND21, and PND75). In addition we measured the expression of the NMDA receptor subunits for the following reasons: (1) NMDA receptors are largely expressed in cortical and hippocampal interneurons, are constitutively active in fast-spiking $\mathrm{PV}^{+}$interneurons, and are critically involved in the generation of gamma frequency oscillations and behavior [22-25]; and, (2) NMDA receptors are physically and functionally linked to mGlu 5 receptors [26-32], and the cross-talk between the two receptors is regulated by the dynamics of the mGlu5/Homer protein complex in dendritic spines [33]. We report that all NMDA receptor subunits are overexpressed in the prefrontal cortex and hippocampus of mGlu5 receptor knockout mice at PND21, but not in the adult life. Developmental alterations in the expression of NMDA receptor subunits were paralleled by changes in MK-801-induced locomotor hyperactivity, which reflects the inhibition of NMDA receptors expressed by GABAergic interneurons.

\section{Material and methods}

\section{Animals}

mGlu5 receptor knockout B6;129-Grm5 $5^{\text {tm1Rod }} / \mathrm{J}$ $\left(\mathrm{mGluR5}^{-l-}\right)$ mice [34] were purchased from The Jackson Laboratory (Bar Harbor, ME, USA). Wild-type and knockout mice were generated by mating male and female heterozygous parents, with the genotypes determined by PCR (Jackson lab protocol). We used mGlu5 ${ }^{-1-}$ mice and wild-type littermates of both sex at PND9, and exclusively male mice at PND21 and PND75. Mice were housed in an animal care facility at $23{ }^{\circ} \mathrm{C}$ on a $12 \mathrm{~h} \mathrm{light} / 12 \mathrm{~h}$ dark cycle with food and water provided ad libitum. All mice that we used were sacrificed by cervical dislocation. Experiments were performed following the Guidelines for Animal Care and Use of the National Institutes of Health to minimize the number of animals and animal suffering. The experimental protocol was approved by the Ethical Committee of Neuromed Institute (Pozzilli, Italy) and by the Italian Ministry of Health. Animals at PND9, PND21, and PND75 were used for biochemical analysis of interneuron-related genes and NMDA receptor 
subunits. Animals at PND21, and PND75 were used for the assessment of MK-801 induce locomotor activity.

\section{Measurements of mRNA levels of interneuron-related genes}

Mice were killed by decapitation at PND9, PND21 or PND75. The brains were removed and the prefrontal cortex and hippocampus immediately dissected and frozen on liquid nitrogen. Total RNA was extracted using the Trizol reagent (Invitrogen, Carlsbad, CA) according to manufacturer's instructions. The RNA was further treated with DNase (Qiagen, Hilden, Germany), and single strand cDNA was synthesized from $1.5 \mu \mathrm{g}$ of total RNA using Superscript III (Invitrogen) and random hexamers as previously described [35]. Real-time PCR was performed on $15 \mathrm{ng}$ of cDNA by using specific primers and Power SYBR Green Master Mix (Biorad, Hercules, CA) on an Applied Biosystems Step-One instrument.

Thermal cycler conditions were as follows: $10 \mathrm{~min}$ at $95{ }^{\circ} \mathrm{C}, 40$ cycles of denaturation $\left(15 \mathrm{~s}\right.$ at $\left.95^{\circ} \mathrm{C}\right)$, and combined annealing/extension $\left(1 \mathrm{~min}\right.$ at $\left.58-60^{\circ} \mathrm{C}\right)$. The sequence of the specific primers is shown in Table 1: mRNA copy number for each gene was calculated from serially diluted standard curves simultaneously amplified with the samples and normalized with respect to the transferrin receptor (TFRC) mRNA copy number. Each sample was analyzed in duplicate together with two negative controls.

\section{Western blot analysis of NMDA receptor subunits}

GluN1, GluN2A, GluN2B, and GluN2D receptor subtype protein levels were examined in the prefrontal cortex and hippocampus at PND9, PND21 and PND75. Tissue was dissected out and homogenized at $4{ }^{\circ} \mathrm{C}$ in a buffered solution and used for Western blot analysis as reported previously [35]. The following primary antibodies were used: rabbit monoclonal anti-NMDAR1 (Abcam, Cambridge, UK \#ab109182; 1:5000); rabbit monoclonal anti-NMDAR2A (Abcam, \#ab14596; 1:1500); mouse monoclonal anti-NMDAR2B (Abcam, \#ab28373; 1:500); rabbit monoclonal anti-NMDAR2D (Abcam, \#ab35448; 1:1000); mouse monoclonal anti-GAPDH (Santa Cruz Biotechnology, Dallas, Texas, sc-32233; 1:1000).
Immunostaining was revealed by the enhanced ECL Western blotting analysis system (Hybond ECL, GE Healthcare Europe) and by the Chemidoc computerized densitometer (Bio-Rad). The Immunoblots signal was quantified by ImageJ software.

\section{Assessment of MK-801-stimulated locomotor activity}

(5S,10R)-(+)-5-Methyl-10,11-dihydro-5H-dibenzo[a,d] cyclohepten-5,10-imine maleate (MK-801), was purchased from Tocris Bioscience (Bristol, U.K.). MK801-induced hyperactivity was assessed in an open-field apparatus. The latter consisted of an unfamiliar cubic box $(42 \times 42 \times 21 \mathrm{~cm})$ with its top left uncovered and transparent plastic walls. The box was connected to an Activity Monitor equipped with infrared photobeam interruption sensor and animal movements were measured and recorded by a computerized analysis system (Open Field Activity System Hardware; Med Associates, Inc., St. Albans, U.K.). On the day of the experiment mice were transferred to the testing room and left in the open field apparatus to record basal locomotor activity for $60 \mathrm{~min}$. Afterwards, they were treated i.p. with MK-801 (0.32 mg/kg or $0.64 \mathrm{mg} / \mathrm{kg})$ and positioned back into the box, where locomotor activity was recorder for additional 120 min defined as "hyperactivity phase". The software was set to record the distance travelled by mice every $5 \mathrm{~min}$ for a total of $180 \mathrm{~min}$. Locomotor activity was expressed as a function of time in 5 min beans (line graphs) or accumulated activity during the habituation phase and hyperactivity phase.

\section{Statistical analysis}

Statistical analysis of biochemical data was carried out by Student's t test. Statistical analysis for locomotor activity was carried out by One-way ANOVA for repeated measures followed by Fisher's Least Significant Difference (LSD).

\section{Results \\ Developmental profile of interneuron-related genes in the prefrontal cortex and hippocampus of $\mathrm{mGlu5}^{-/-}$mice}

We first measured the transcripts of interneuron-related genes in the prefrontal cortex and hippocampus of mGlu $5^{-/-}$mice and their wild-type littermates at three developmental stages (PND9, PND21, and PND75). We focused on GAD1 and GAD2, encoding the two isoforms

\footnotetext{
(See figure on next page.)

Fig. 1 Influence of genetic deletion of mGlu5 receptors on the expression of interneuron-related genes in the prefrontal cortex and hippocampus across postnatal development. mRNA levels encoding interneuron-related proteins in the prefrontal cortex and hippocampus at PND9-21 and -75 are shown in $\mathbf{a}$ and $\mathbf{b}$, respectively. Values are means \pm S.E.M. of 5-9 mice per group. ${ }^{*} p<0.05$ vs. the corresponding values of wild-type littermates (Student's t-test). a PND9: Pvalb, $t_{10}=2.3$; Reln, $t_{10}=5.6 ; V_{i p} t_{10}=5.6 ;$ PND21: GAD1, $t_{11}=4 ;$ Pvalb, $t_{11}=3.1 ;$ PND75: GAD2, $t_{5}=2.8$, Pvalb, $t_{5}=3.2$, Vip, $\mathrm{t}_{5}=2.6 . \mathbf{b}$ PND9: Pvalb, $\mathrm{t}_{8}=11.1 ;$ Reln, $\mathrm{t}_{7}=3.5 ;$ PND21: Vip, $\mathrm{t}_{9}=2.2 ;$ PND75: SSt, $\mathrm{t}_{6}=6.2$
} 


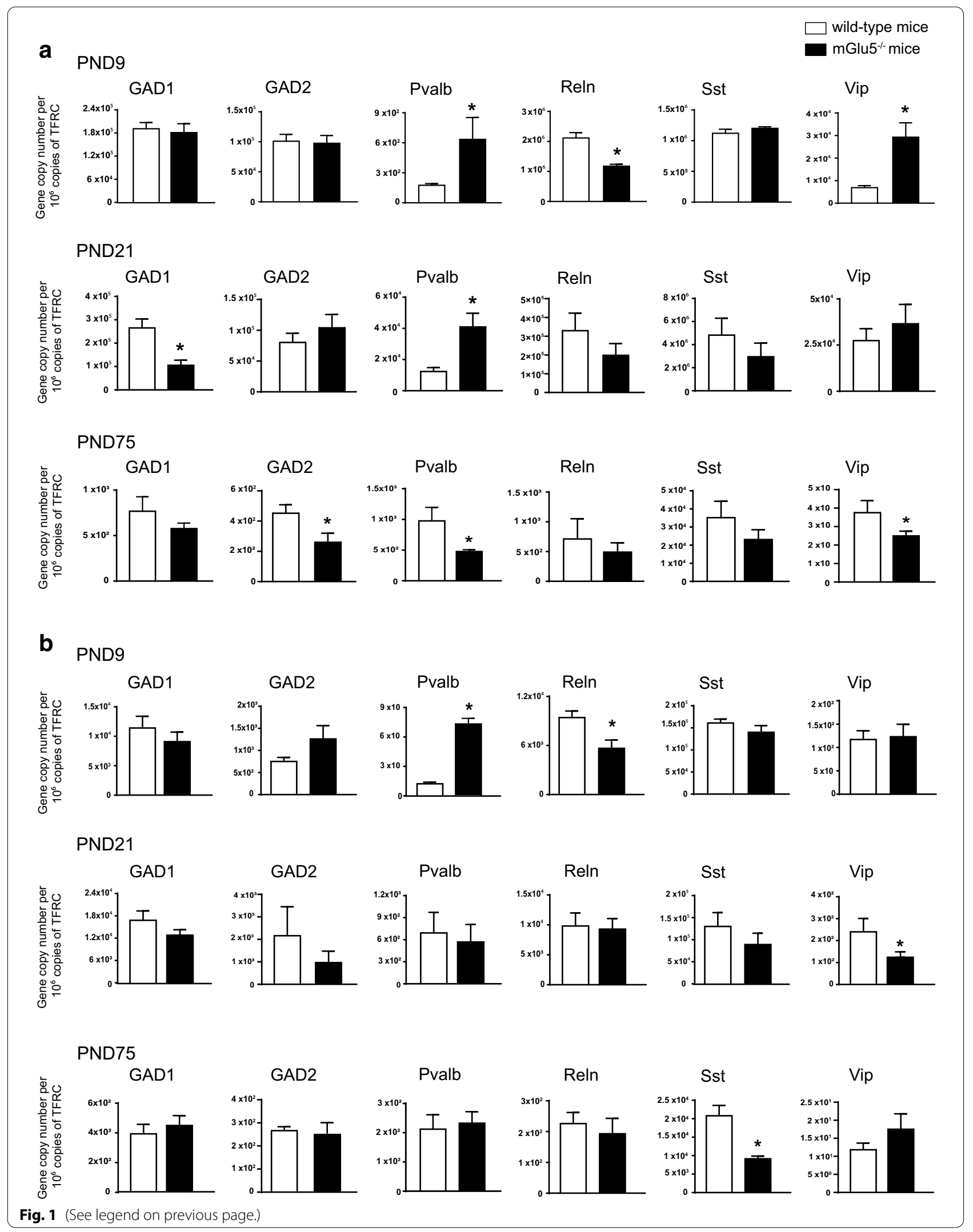


of the GABA-synthesizing enzyme, glutamate decarboxylase (GAD67 and GAD65) respectively; Pvalb and SSt, encoding PV and somatostatin (SSt), which are expressed by the two major interneuron populations originating from the medial ganglionic eminence; and Reln and Vip, encoding Reelin and vasoactive intestinal peptide (Vip), as representative biomarkers of interneurons originating from the caudal ganglionic eminence [36].

\section{a. Prefrontal cortex}

Changes in Pvalb and Vip expression in $\mathrm{mGlu}^{-1-}$ mice were not uniform in the three selected developmental time points. Pvalb expression was significantly increased at PND9 and PND21, and reduced at PND75, as compared to wild-type littermates (Fig. 1a). Similarly, Vip expression showed a significant increase at PND9, a trend to an increase at PND21, and a significant reduction at PND75 (Fig. 1a). Reln expression in $\mathrm{mGlu}^{-1-}$ mice was exclusively reduced at PND9, whereas SSt expression did not differ between the two genotypes at all developmental time points (Fig. 1a). GAD1 was reduced in $\mathrm{mGlu}^{-1-}$ mice at PND21, whereas GAD2 was reduced at PND75 (Fig. 1a).

b. Hippocampus

Changes in the expression of interneuron-related genes were less substantial in the hippocampus of $\mathrm{mGlu}^{-1-}$ mice compared to wild-type littermates across postnatal development. Similarly to the prefrontal cortex, Pvalb expression was significantly increased in $\mathrm{mGlu}^{-1-}$ mice at PND9, but did not change at PND21 and PND75 (Fig. 1b). Reln expression was reduced in $\mathrm{mGlu}^{-1-}$ mice at PND9, whereas Vip and SSt expression was reduced at PND21 and PND75, respectively (Fig. 1b). No other differences in gene expression between $\mathrm{mGlu}^{-/-}$ mice and wild-type littermates were found in the hippocampus (Fig. 1b).

\section{Developmental change in the expression of NMDA receptor subunits in $\mathrm{mGlu5}^{-/-}$mice}

We studied the expression of NMDA receptor subunits in the prefrontal cortex and hippocampus of mGlu $5^{-1-}$ mice and wild-type littermates because NMDA receptors are structurally and functionally coupled to mGlu5 receptors, and are highly functional in GABAergic interneurons (see "Introduction" and References therein). We found substantial changes in the transcript and protein levels of NMDA receptor subunits in both brain regions of mGlu5 ${ }^{-1-}$ mice at PND9 and PND21 but not in the adult life (PND75).

\section{a. Prefrontal cortex}

At PND9, there was only a partial correspondence between transcript and protein levels of the five selected NMDA receptor subunits (GluN1, and Gln2A-D). Expression of Grin2A and Grin2C genes, encoding GluN2A and GluN2C subunits, respectively, was largely increased in $\mathrm{mGlu}^{-/}$mice, as compared to wild-type littermates, whereas the other transcripts did not change (Fig. 2a). Immunoblot analysis showed a significant increase in GluN1 and GluN2B protein levels, whereas GluN2A and GluN2D levels were significantly reduced in mGlu $5^{-1-}$ mice (Fig. 2b). We were unable to detect the GluN2C subunit under our conditions (using three commercially available antibodies).

It was at PND21 that we found the largest changes in NMDA receptor subunits in $\mathrm{mGlu}^{-/-}$mice. At this time point, expression of Grin1 and Grin2A was largely increased, whereas Grin2B expression was nearly suppressed (Fig. 2c). Remarkably, mGlu $5^{-1-}$ mice showed a substantial increase in GluN1, GluN2B, and GluN2D protein levels, and a smaller increase in GluN2A levels at PND21 (Fig. 2d). Again, all changes in the transcript and protein levels of NMDA receptor subunits between mGlu $5^{-1-}$ mice and wild-type littermates disappeared at PND75 in the prefrontal cortex (Fig. 4a, b).

b. Hippocampus

In the hippocampus, transcript and protein levels of NMDA receptor subunits were divergent at PND9 and PND21. At PND9, Grin2A and Grin2C expression was significantly increased in $\mathrm{mGlu}^{-1-}$ mice, as compared to wild-type littermates (Fig. 3a). In contrast, GluN2B protein levels were increased, GluN2A and GluN2D levels were reduced, and GluN1 levels did not change in $\mathrm{mGlu} 5^{-1-}$ mice at this time point (Fig. 3b). At PND21 only Grin2C transcript lev-

(See figure on next page.)

Fig. 2 Expression of NMDA receptor subunits in the prefrontal cortex of $\mathrm{mGlu} 5^{-/-}$mice and wild-type littermates at PND9 and PND21. mRNA and protein levels at PND9 and PND21 are shown in $\mathbf{a}, \mathbf{c}$ and $\mathbf{b}$, d, respectively. Values are means \pm S.E.M. of $4-9$ mice per group. ${ }^{*} p<0.05$ (Student's t-test). a Grin2A, $t_{10}=3.8 ;$ Grin2C, $t_{9}=2.8 ; \mathbf{b}$ GluN1, $t_{8}=3.4 ; G l u N 2 A, t_{9}=9.4 ; G l u N 2 B, t_{8}=2.8 ; G l u N 2 D, t_{9}=9.4$ c Grin1, $t_{12}=4.6 ; G \operatorname{Gin} 2 A, t_{13}=2.5$; Grin2B, $t_{12}=3.4$ d GluN1, $t_{9}=7 ;$ GluN2A, $t_{8}=4.1 ; G l u N 2 B, t_{10}=3.4 ; G l u N 2 D, t_{9}=7$. Uncropped western blots are shown 


\section{PND9 Prefrontal cortex}

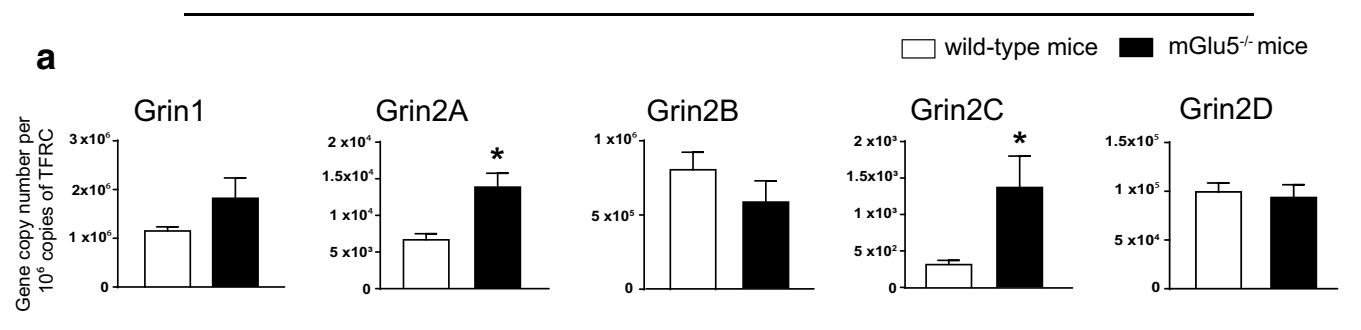

b

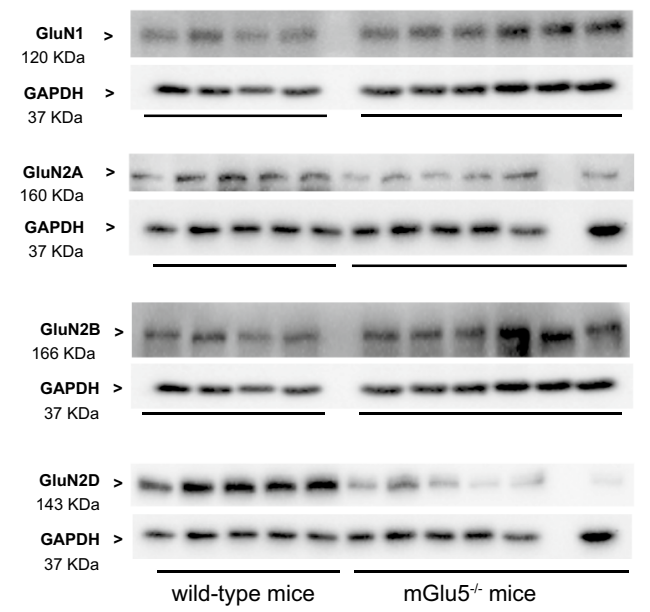

$\square$ wild-type mice $\square$ mGlu5 ${ }^{-/-}$mice
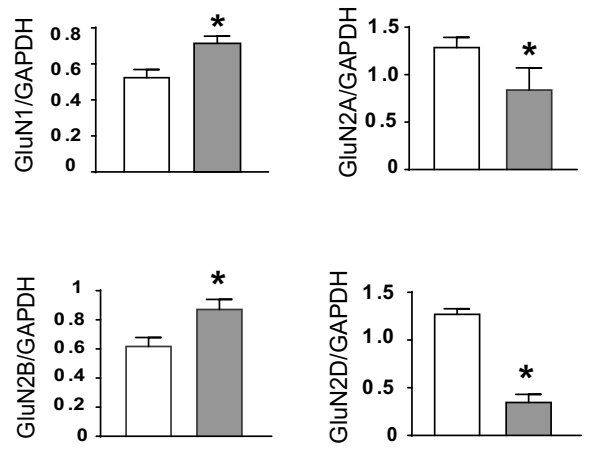

PND21 Prefrontal cortex

C

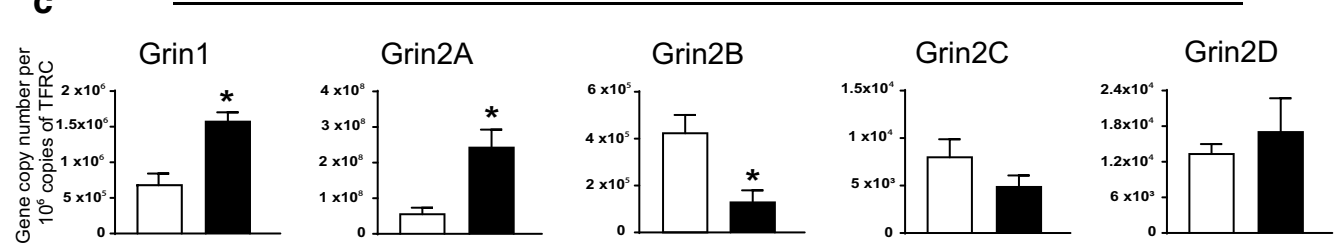

d
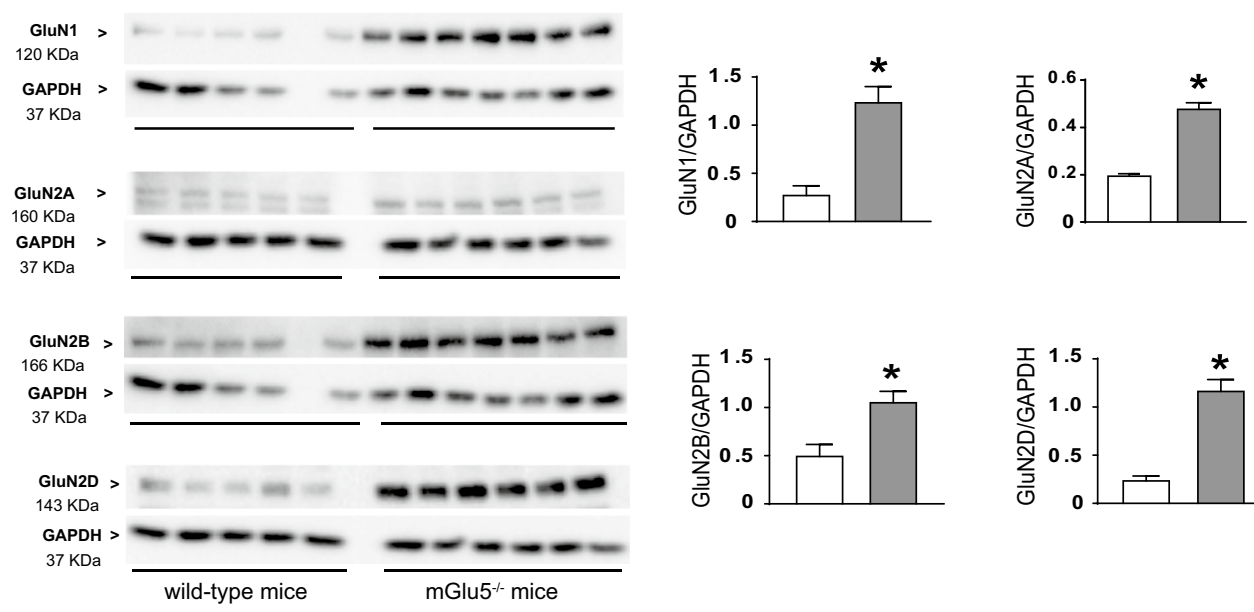

Fig. 2 (See legend on previous page.) 
els showed a significant increase in $\mathrm{mGlu}^{-1-}$ mice (Fig. 3c), whereas protein levels of GluN1, GluN2B and GluN2D were largely increased (Fig. 3d). At PND75, no changes in transcript and protein levels of NMDA receptor subunits were found in $\mathrm{mGlu}^{-1-}$ mice as compared to wild-type littermates (Fig. 4c, d).

\section{Changes in MK-801-induced hyperactivity in $\mathrm{mGlu5}^{-/-}$ mice at PND21 that is inverted at PND75}

Moving from the overexpression of NMDA receptor subunits found in $\mathrm{mGlu}^{-/-}$mice at PND21, we examined whether this could be paralleled by changes in the behavioral response to the slow NMDA channel blocker, MK-801. Of note, MK-801-induced hyperactivity is widely used as an experimental animal model of psychosis [37]. After $60 \mathrm{~min}$ of habituation to the open field apparatus, mice were injected with MK-801, and motor activity was recorded for additional $120 \mathrm{~min}$. At PND21, mice did not respond to the standard dose of MK-801 used in our laboratories $(0.32 \mathrm{mg} / \mathrm{kg}$, i.p.) (Fig. 5a), and, therefore, we decided to repeat the experiment doubling the dose of MK-801. In response to $0.64 \mathrm{mg} / \mathrm{kg}$ of MK-801 both $\mathrm{mGlu}^{-1-}$ mice and wild-type littermates showed a significant increase in locomotor activity, which lasted for at least $90 \mathrm{~min}$. However, the response to MK-801 was much greater in $\mathrm{mGlu}^{-1-}$ mice, with no significant difference between the two genotypes in the habituation phase (Fig. 5b). As expected, adult mice (PND75) responded to $0.32 \mathrm{mg} / \mathrm{kg}$ of MK-801, but the increase in locomotor activity was less pronounced in mGlu $5^{-1-}$ mice, as compared to wild-type littermates (Fig. 5c). There was no difference between the two genotypes when PND75 mice were challenged with $0.64 \mathrm{mg} /$ kg of MK-801 (Fig. 5d).

\section{Discussion}

Functional NMDA receptors are heterotetramers typically formed by two GluN1 subunits and two GluN2 subunits. GluN2A, GluN2B; GluN2C, and GluN2D subunits are encoded by four different genes (Grin2A-D) [38, 39]. The GluN1 subunit is ubiquitously expressed with no major developmental changes, whereas the expression pattern of GluN2 subunits shows remarkable changes across postnatal development. The GluN2A subunit starts to be expressed early after birth and expression progressively increases afterwards, whereas the GluN2D subunit shows an opposite expression profile. Expression of the GluN2B subunit is ubiquitous in the first two weeks of postnatal life, and becomes restricted to the forebrain in the adult life. The GluN2C subunit begins to be expressed at PND10, and expression is mainly confined to the cerebellum. The most remarkable developmental change in NMDA receptor composition is the switch between GluN2B- to GluN2A-containing heterotetramers at a time that coincides with synaptic maturation, and circuit refinement [39].

Absolute levels of Grin1 and Grin2A-D transcripts in the prefrontal cortex and hippocampus of wild-type mice changed during postnatal development as reported previously [39], although we were surprised to find high expression levels of Grin2C mRNA at PND75. Expression of NMDA subunit protein levels was only studied comparatively between $\mathrm{mGlu} 5^{-1-}$ and wild-type littermates without comparing levels of the same strain at the different time points. Interestingly, we found a large overexpression of the GluN2B subunit at both PND9 and PND21 in both prefrontal cortex and hippocampus of mGlu $5^{-1-}$ mice, as compared to wild-type littermates. This was associated with a significant reduction of the GluN2A subunit at PND9, but not at PND21. These findings suggest that the lack of mGlu5 receptors delays the developmental shift between the GluN2B and the GluN2A subunit, which normally occurs after the first 7-10 days of postnatal life [40]. This is in nice agreement with electrophysiological data showing that the developmental switch between GluN2B and GluN2A (formerly named NR2B and NR2A) is defective or absent in the hippocampus and visual cortex of mGlu5 receptor knockout mice [41]. A leading hypothesis is that endogenous activation of mGlu5 receptors promotes the removal of GluN2B-containing NMDA receptors from the plasma membrane through a mechanism mediated by casein kinase 2 [39]. The lack of changes in Grin2B transcript levels between $\mathrm{mGlu}^{-1-}$ and wild-type mice at PND9 supports the hypothesis that mGlu5 receptors regulates the GluN2B/GluN2A balance at protein level $[39,41]$. Our data also raise the interesting possibility that mGlu5 receptors critically regulate the expression of the GluN2D subunit, which was largely reduced at PND9 and increased at PND21 in $\mathrm{mGlu}^{-/-}$mice, with respect

\footnotetext{
(See figure on next page.)

Fig. 3 Expression of NMDA receptor subunits in the hippocampus of $\mathrm{mGlu} 5^{-/-}$mice and wild-type littermates at PND9 and PND21. $\mathrm{mRNA}$ and protein levels at PND9 and PND21 are shown in $\mathbf{a}-\mathbf{d}$. Values are means \pm S.E.M. of 4-9 mice per group. ${ }^{*} \mathrm{p}<0.05$ (Student's t-test). a Grin2A, $\mathrm{t}_{9}=3.5 ;$ Grin2C, $\mathrm{t}_{9}=2.5 ; \mathbf{b}$ GluN2A, $\mathrm{t}_{10}=4 ; \mathrm{GluN2B}, \mathrm{t}_{9}=2.7 ; \mathrm{GluN2D}, \mathrm{t}_{10}=7 ; \mathbf{c}$ Grin2C, $\mathrm{t}_{11}=2.5 ; \mathbf{d}$ GluN1, $\mathrm{t}_{10}=2.8 ; \mathrm{GluN}_{2} \mathrm{~B}, \mathrm{t}_{9}=5.2 ; \mathrm{GluN2D}, \mathrm{t}_{10}=5.2$. Uncropped western blots are shown
} 


\section{PND9 Hippocampus}

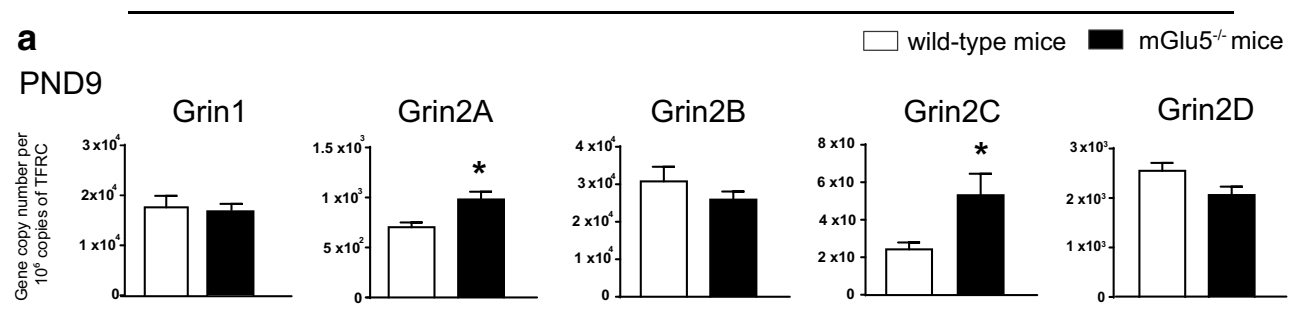

b

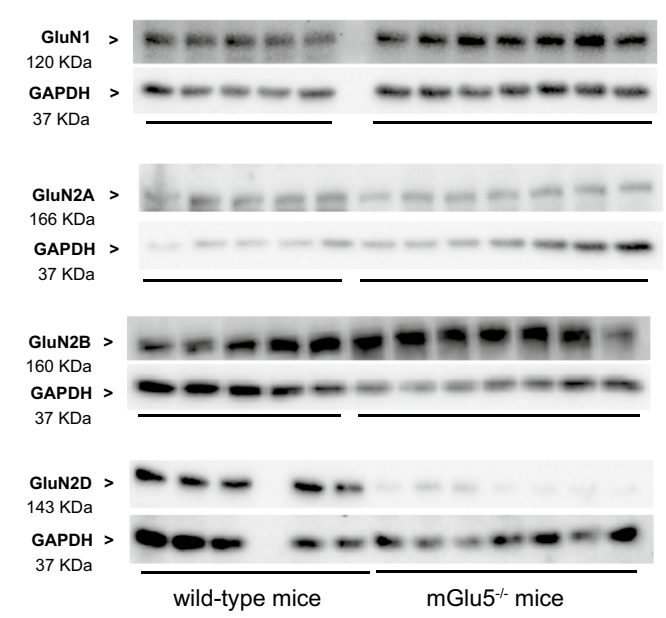

$\square$ wild-type mice $\square$ mGlu5 ${ }^{-- \text {mice }}$
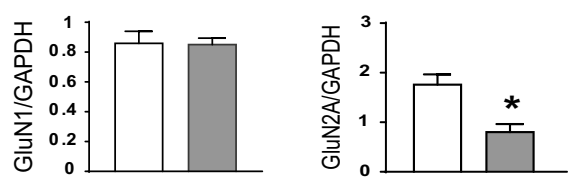

C
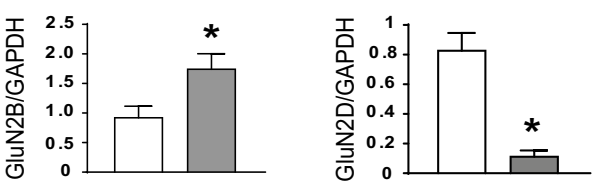

PND21 Hippocampus

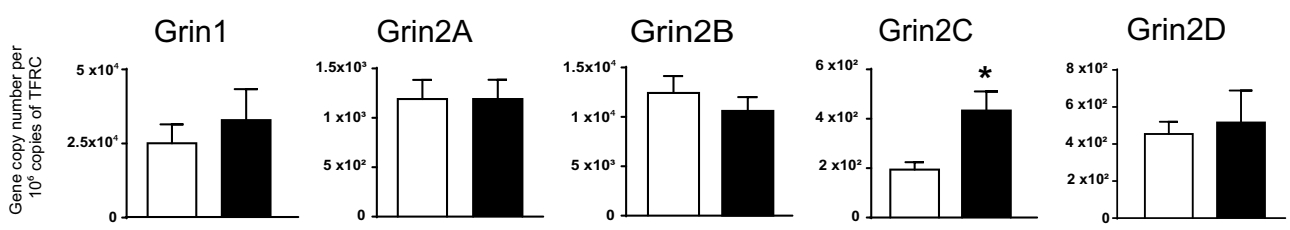

d
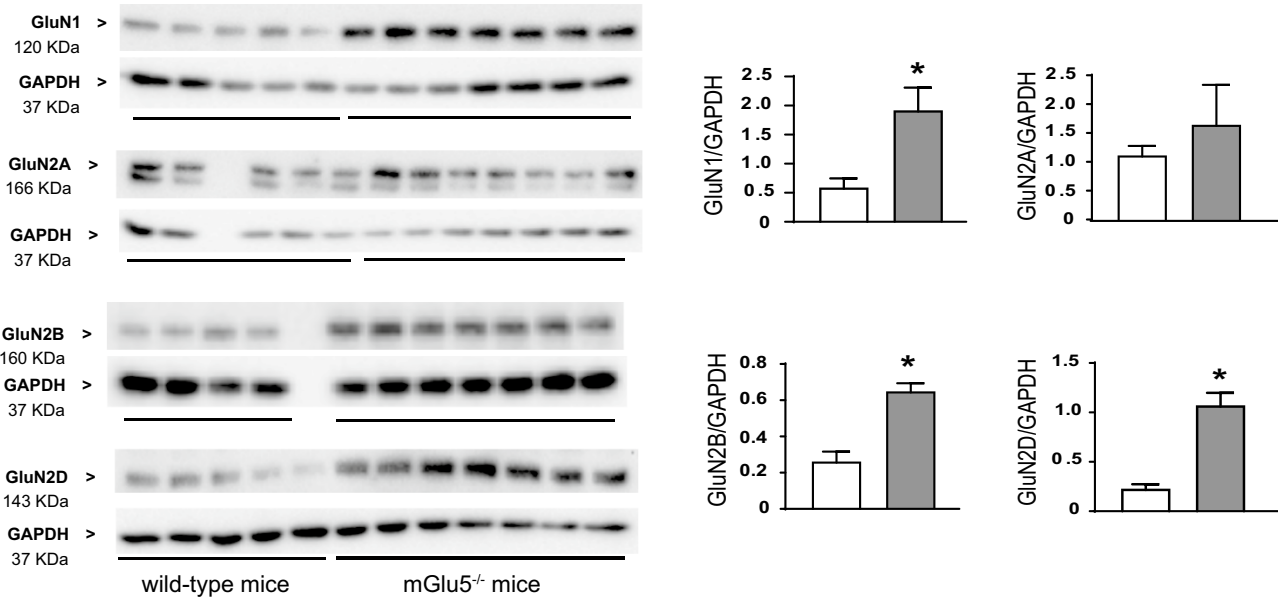

Fig. 3 (See legend on previous page.)
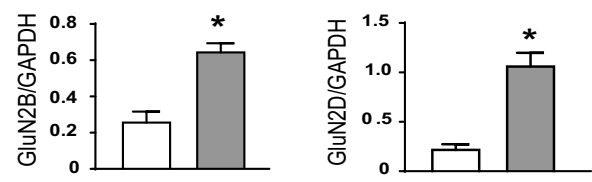


\section{PND75 Prefrontal cortex}

a

Grin1

Grin2A

Grin2B

$\square$ wild-type mice

mGlu5 $5^{-1-m i c e}$
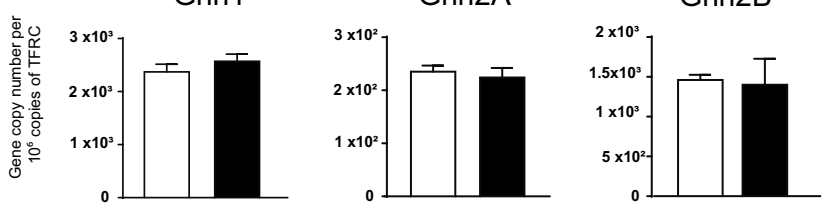

Grin2C

Grin2D

b

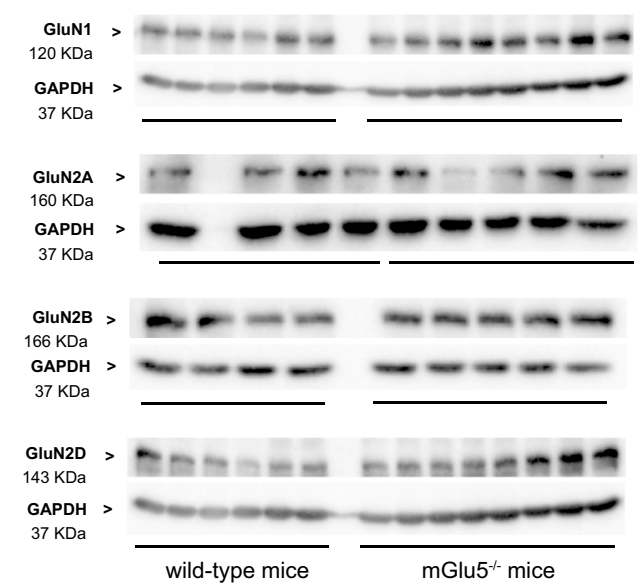

$\square$ wild-type mice $\square$ mGlu5 ${ }^{--}$mice
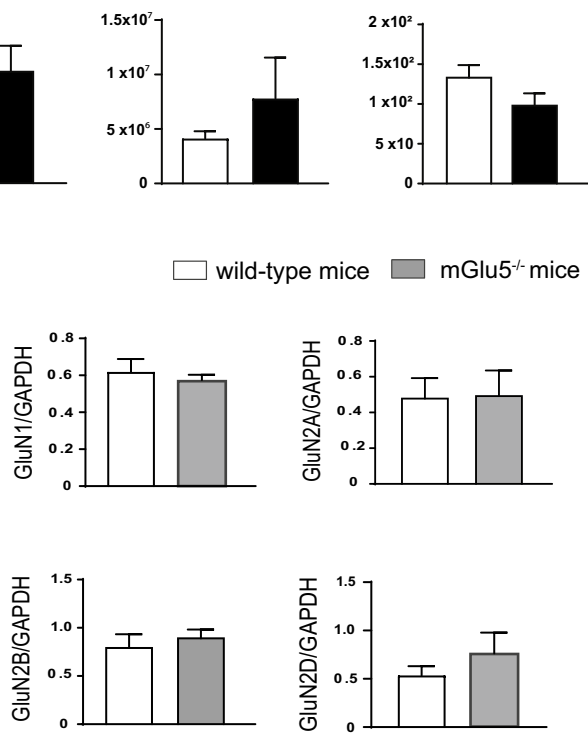

C

PND75 Hippocampus

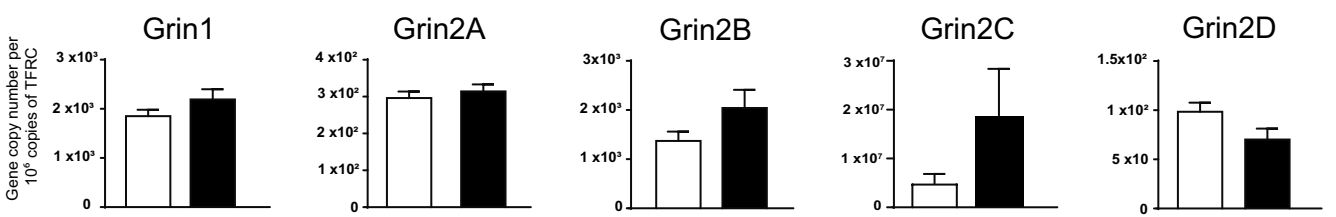

d
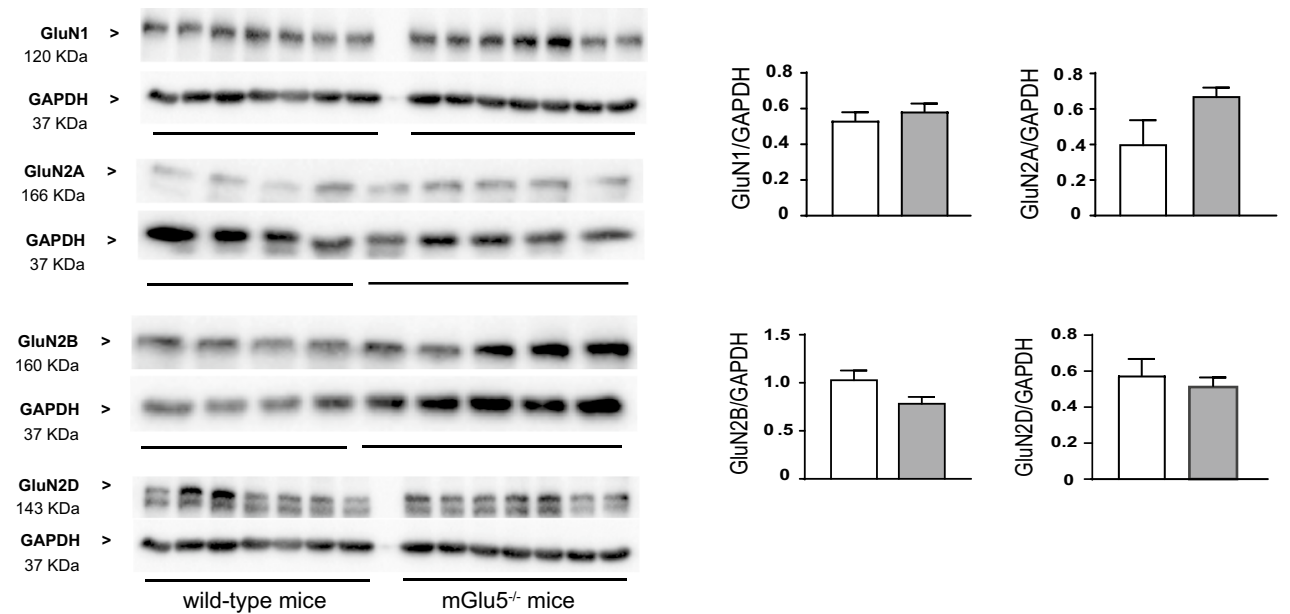

Fig. 4 Expression of NMDA receptor subunits in the prefrontal cortex and hippocampus of mGlu5 ${ }^{-/}$mice and wild-type littermates at PND75. mRNA and protein levels in the prefrontal cortex and hippocampus are shown in a-d. Values are means \pm S.E.M. of 4-6 mice per group. Uncropped western blots are shown 
to wild-type littermates. The Grin2D transcripts did not change in both regions in the two time points, suggesting again that mGlu5 receptors act at post-transcriptional levels in regulating Grin2D mRNA translation and/or GluN2B protein stability. This hypothesis warrants further investigation.

We could only measure the transcript of Grin $2 \mathrm{C}$, which was largely increased in the prefrontal cortex at PND9 and in the hippocampus at both PND9 and PND21. The significance of these changes is uncertain because, at least in the hippocampus and cerebral cortex, GluN2C is not expressed by neurons but co-localizes with astrocytic markers [42].

At least in the prefrontal cortex, the general overexpression of NMDA receptor subunits might contribute to explain the unexpected increase in Pvalb transcript observed at PND9 and PND21. In fast-spiking $\mathrm{PV}^{+}$ interneurons NMDA receptors are constitutively active owing to membrane depolarization, which removes the $\mathrm{Mg}^{2+}$ blockade of the NMDA-gated ion channel (see "Introduction" and References therein). An increased expression of NMDA receptors in the prefrontal cortex of mGlu $5^{-1-}$ mice at PND9 and PND21 might cause a hyperactivation of $\mathrm{PV}^{+}$interneurons with a resulting increase in Pvalb gene expression [43]. This might represent a compensatory mechanism aimed at buffering the increased influx of extracellular $\mathrm{Ca}^{2+}$ through the NMDA-gated ion channel. In the hippocampus, the increase in the transcript encoding PV was found at PND9, when an increase in GluN2B subunit was associated with a reduction in GluN2A and GluN2D, and no changes in GluN1 protein levels. In contrast, no changes in Pvalb transcript were seen at PND21, when GluN1, GluN2B, and GluN2D (but not GluN2A) protein levels were increased. It is possible that the presence of the GluN2A subunit is required for the regulation of Pvalb expression by NMDA receptors at PND21 (but not at PND9). This is supported by data obtained in cultured cortical neurons, in which selective blockade of GluN2A-containing NMDA receptors decreased PV and GAD67 immunoreactivity [43].

The transcripts encoding Vip and Reelin, which are two makers of interneurons originating from the caudal portion of ganglionic eminences [36], showed changes at PND9, with Reln transcript being decreased in both prefrontal cortex and hippocampus, and Vip transcript increased in the prefrontal cortex. At PND75, there was a reduction in the transcript encoding PV, GAD65, and VIP in the prefrontal cortex, and a reduction in the transcript encoding SSt in the hippocampus. These results are partially consistent with a previous report [18] showing a reduction in PV mRNA levels in the prefrontal/frontal cortex (but not in the hippocampus), a reduction in SSt mRNA levels in the hippocampus, and a reduction in GAD65 and GAD67 mRNA levels in the prefrontal cortex/frontal cortex and hippocampus of adult (PND $>80)$ male $m G l u 5^{-1-}$ mice. In our study, protein levels of NMDA receptor subunits were normalized in mGlu5 $5^{-1-}$ mice at PND75, and this might have disclosed an intrinsic defect in PV expression in the prefrontal cortex and SSt expression in the hippocampus caused by the lack of mGlu5 receptors. Changes in the Pvalb and SSt transcripts seen in adult mGlu $5^{-1-}$ mice are consistent with the view that these mice recapitulate some of the biochemical and behavioral hallmarks of schizophrenia [18, 19, 34].

The most relevant finding of our study was that mGlu5 $5^{-1-}$ mice showed an impressive increase in GluN1, GluN2A, GluN2B, and GluN2D protein levels in the prefrontal cortex and hippocampus at the time of weaning (PND21), while levels returned back to normal in the adult life. This indicates that the lack of mGlu5 receptors is compensated by an increased expression of its receptor partner (the NMDA receptor) during postnatal development, to limit the potential abnormalities in network activity resulting from the absence of mGlu5 receptors in interneurons. However, this compensatory mechanism is transient and not sufficient to avoid the development of a pathological phenotype in the adult life. We reasoned that, if overexpression of NMDA receptors was a compensatory mechanism at PND21, we could unmask a psychotic-like behavioral phenotype by blocking NMDA receptors. For this reason, we assessed locomotor activity in response to the slow NMDA channel blocker, MK-801. MK-801-induced hyperactivity in rodents is widely used as a model for positive symptoms of schizophrenia [44], which is sensitive to both classical and atypical antipsychotic drugs [45]. Under our experimental conditions, wild-type mice at PND21 did not respond to conventional doses of MK-801 $(0.32 \mathrm{mg} / \mathrm{kg})$

\footnotetext{
(See figure on next page.)

Fig. 5 MK-801-induced hyperactivity in $\mathrm{mGlu}^{-/-}$mice and wild-type littermates at PND21 and PND75. Locomotor activity in response to 0.32 mg/ $\mathrm{kg}$ or $0.64 \mathrm{mg} / \mathrm{kg} \mathrm{MK-801}$ at PND21 and in response to $0.32 \mathrm{mg} / \mathrm{kg}$ or $0.64 \mathrm{mg} / \mathrm{kg}$ MK-801 at PND75 is shown in a-d. Mice were habituated to the environment for 60 min prior to the i.p. injection of MK-801. Values are means \pm S.E.M. of 10 wild-type and 3 mGlu5 ${ }^{-/-}$mice in a, 5 wild-type and 6 mGlu $5^{-1-}$ mice in $\mathbf{b}, 7$ wild-type and 5 mGlu5 ${ }^{-1-}$ mice in $\mathbf{c}, 7$ wild-type and 4 mGlu $5^{-1-}$ mice in $\mathbf{d}$. Open bars $=$ habituation phase; closed bars $=$ response to MK-801. ${ }^{*} p<0.05$ vs. wild-type mice (One-way ANOVA for repeated measures). $\mathbf{b}, F_{1,119}=27.875 ; p<0.001 ; \mathbf{c} F_{1,119}=44.692$; $p<0.001$
} 


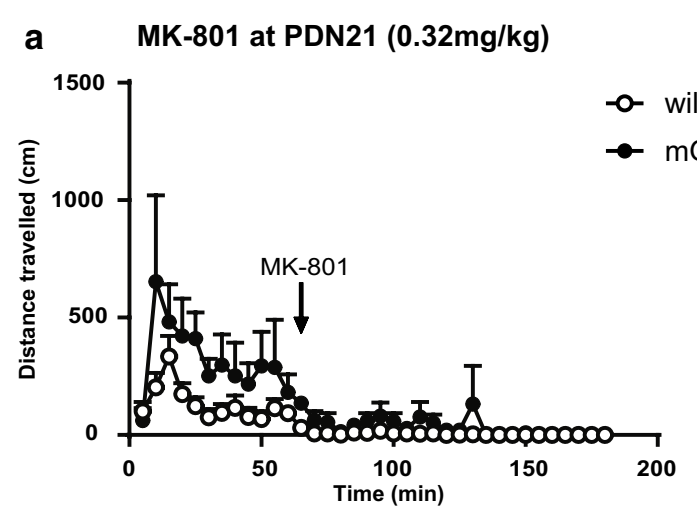

b MK-801 at PDN21 (0.64mg/kg)
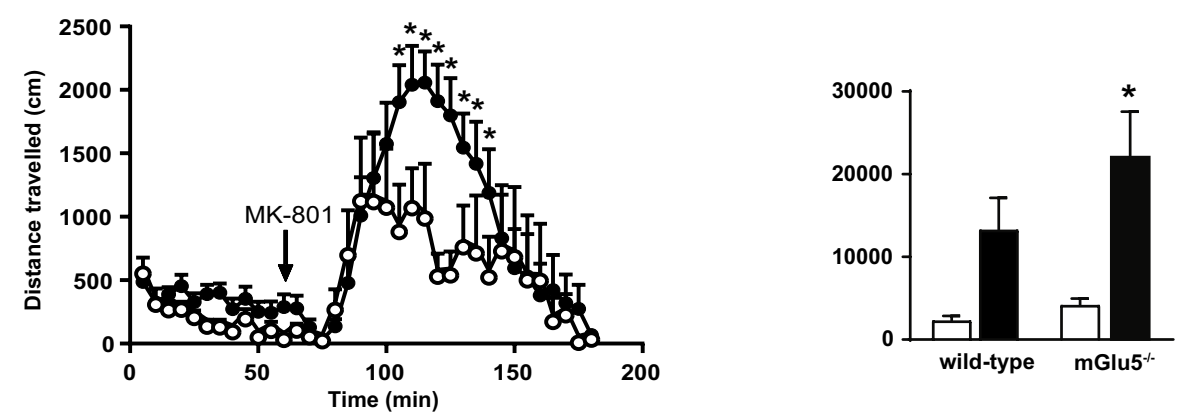

C MK-801 at PND75 (0.32mg/kg)
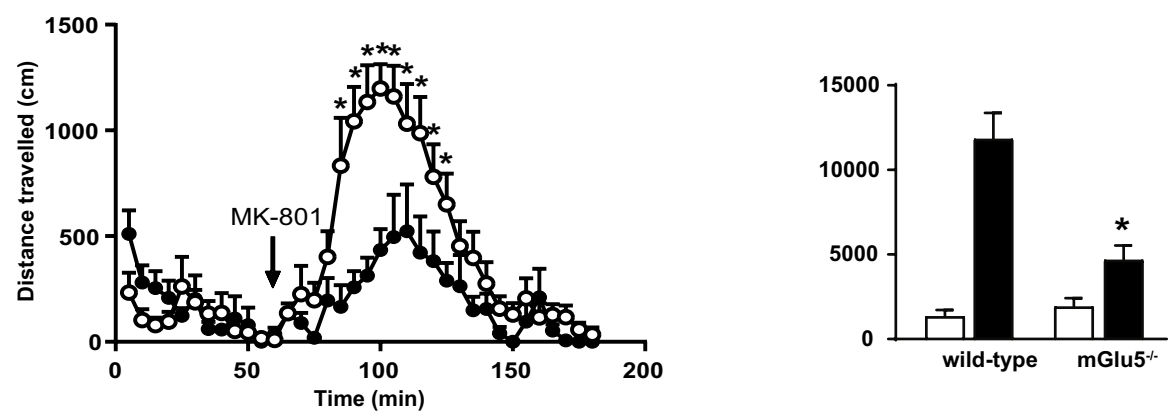

d MK-801 at PND75 (0.64 mg/kg)
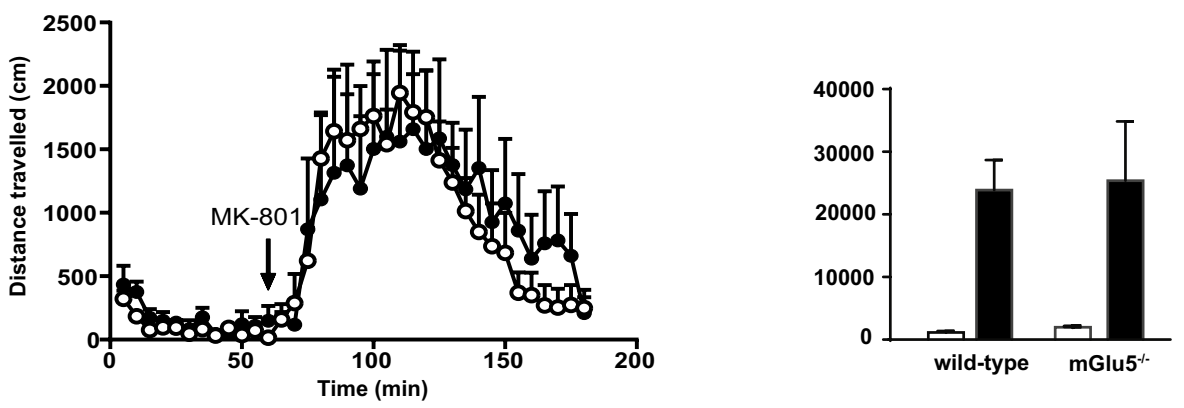

Figure 5

Fig. 5 (See legend on previous page.) 
[46], and, therefore, a double dose was required for the induction of hyperactivity in these mice. Interestingly, mGlu5 ${ }^{-1-}$ mice at PND21 displayed a large increase in MK-801-induced hyperactivity as compared to wild-type littermates, supporting the hypothesis that the overexpression of NMDA receptors represents an important compensatory mechanism in $\mathrm{mGlu}^{-1-}$ mice at this developmental stage. The situation was reversed in the adult life, when hyperactivity was largely attenuated in $\mathrm{mGlu}^{-1-}$ mice in response to $0.32 \mathrm{mg} / \mathrm{kg}$ MK-801. A possible explanation is that, in adult $\mathrm{mGlu}^{-1-}$ mice, normally expressed NMDA receptors are less active in supporting the function of fast-spiking, $\mathrm{PV}^{+}$, interneurons because of the lack of the mGlu5 receptor partner. As a consequence, the behavioral response to NMDA receptor blockade was blunted in these mice.

\section{Conclusions}

In conclusion, our findings further demonstrate a close partnership between mGlu5 and NMDA receptors in the mouse prefrontal cortex and hippocampus, showing that the lack of mGlu5 receptors was compensated by a large but transient overexpression of NMDA receptor subunits during postnatal development. This may have important implications in the behavioral, biochemical, and electrophysiological phenotype of $\mathrm{mGlu}^{-1-}$ mice, and should be taken into account when these mice are used for the study of mechanisms of developmental plasticity.

\begin{abstract}
Abbreviations
NMDA: N-methyl-D-aspartate receptor; mGlu5 receptor: Metabotropic glutamate receptor type 5; PND: Postnatal day; GluN1,2A-D: N-methyl-D-aspartate receptor subunit 1,2A-D; MK-801: (5S,10R)-(+)-5-Methyl-10,11-dihydro5H-dibenzo[a,d]cyclohepten-5,10-imine maleate; PI: Polyphosphoinositide hydrolysis; CNS: Central nervous system; GABA: Gamma-aminobutyric acid; PV: Parvalbumin; PNN: Perineuronal nets; TFRC: Transferrin receptor; GAPDH: Glyceraldehyde 3-phosphate dehydrogenase; ECL: Enhanced chemiluminescence; LSD: Least significant difference; GAD1: Glutamate decarboxylase 1; GAD2: Glutamate decarboxylase 2; Pvalb: Parvalbumin gene; SSt: Somatostatin gene; Reln: Reelin gene; Vip: Vasoactive intestinal peptide gene; Grin 1,2A-D: $\mathrm{N}$-methyl-D-aspartate receptor subunit 1, 2A-D gene; $\mathrm{Mg}^{2+}$ : Magnesium; $\mathrm{Ca}^{2+}$ : Calcium.
\end{abstract}

\section{Acknowledgements}

Not applicable.

\section{Authors' contributions}

FN and MC designed the project. TI and RV, performed real time PCR and western blot experiments. TI, RV and NA, performed MK-801 induced hyperlocomotor activity test. TI, RV and MC carried out the data analysis. FN and MC, wrote the final manuscript. TI and RV contributed to the drafting of the last version. GB and SM helped to revise the manuscript. All authors read and approved the final manuscript.

\section{Funding}

This research is supported by Italian Ministry of Health.

\section{Availability of data and materials}

The data that support the findings of this study are available from the corresponding author upon reasonable request.

\section{Declarations}

Ethics approval and consent to participate

The experimental protocols were performed following the Guidelines for Animal Care and Use of the National Institutes of Health to minimize the number of animals and animal suffering. The experimental protocol was approved by the Ethical Committee of Neuromed Institute (Pozzilli, Italy) and by the Italian Ministry of Health.

\section{Consent for publication}

Not applicable.

\section{Competing interests}

The authors declare no competing or financial interests.

\section{Author details}

${ }^{1}$ IRCCS Neuromed, Pozzilli, IS, Italy. ${ }^{2}$ Department of Physiology and Pharmacology "V. Erspamer", University Sapienza of Rome, Piazzale Aldo Moro, 5, 00185 Rome, Italy. ${ }^{3}$ CNRS, UMR 8576, UGSF, Unité de Glycobiologie Structurale et Fonctionnelle, University of Lille, Lille, France.

Received: 10 March 2021 Accepted: 21 April 2021

Published online: 07 May 2021

\section{References}

1. Nicoletti F, Wroblewski JT, Novelli A, Alho H, Guidotti A, Costa E. The activation of inositol phospholipid metabolism as a signal-transducing system for excitatory amino acids in primary cultures of cerebellar granule cells. J Neurosci. 1986;6(7):1905-11.

2. Pin JP, Duvoisin R. The metabotropic glutamate receptors: structure and functions. Neuropharmacology. 1995;34(1):1-26.

3. Nicoletti F, Bockaert J, Collingridge GL, Conn PJ, Ferraguti F, Schoepp DD, et al. Metabotropic glutamate receptors: from the workbench to the bedside. Neuropharmacology. 2011;60(7-8):1017-41.

4. Catania MV, Landwehrmeyer GB, Testa CM, Standaert DG, Penney JB Jr, Young AB. Metabotropic glutamate receptors are differentially regulated during development. Neuroscience. 1994;61(3):481-95.

5. Casabona G, Knöpfel T, Kuhn R, Gasparini F, Baumann P, Sortino MA, et al. Expression and coupling to polyphosphoinositide hydrolysis of group I metabotropic glutamate receptors in early postnatal and adult rat brain. Eur J Neurosci. 1997;9(1):12-7.

6. Minakami R, lida K, Hirakawa N, Sugiyama H. The expression of two splice variants of metabotropic glutamate receptor subtype 5 in the rat brain and neuronal cells during development. J Neurochem. 1995;65(4):1536-42.

7. Dölen G, Osterweil E, Rao BS, Smith GB, Auerbach BD, Chattarji S, Bear MF. Correction of fragile X syndrome in mice. Neuron. 2007;56(6):955-62.

8. Dölen G, Bear MF. Fragile X syndrome and autism: from disease model to therapeutic targets. J Neurodev Disord. 2009; 1 (2):133-40.

9. Waung MW, Huber KM. Protein translation in synaptic plasticity: mGluRLTD. Fragile X Curr Opin Neurobiol. 2009;19(3):319-26.

10. Conn PJ, Lindsley CW, Jones CK. Activation of metabotropic glutamate receptors as a novel approach for the treatment of schizophrenia. Trends Pharmacol Sci. 2009;30(1):25-31.

11. Julie G, Hamdan FF, Rouleau GA. A strategy to identify de novo mutations in common disorders such as autism and schizophrenia. J Vis Exp. 2011;52:2534.

12. D'Antoni S, Spatuzza M, Bonaccorso CM, Musumeci SA, Ciranna L, Nicoletti F, et al. Dysregulation of group-I metabotropic glutamate (mGlu) receptor mediated signalling in disorders associated with Intellectual Disability and Autism. Neurosci Biobehav Rev. 2014;46(Pt 2):228-41.

13. Pignatelli M, Piccinin S, Molinaro G, Di Menna L, Riozzi B, Cannella M, et al. Changes in mGlu5 receptor-dependent synaptic plasticity and coupling to homer proteins in the hippocampus of Ube3A hemizygous mice modeling angelman syndrome. J Neurosci. 2014;34(13):4558-66.

14. Walker AG, Conn PJ. Group I and group II metabotropic glutamate receptor allosteric modulators as novel potential antipsychotics. Curr Opin Pharmacol. 2015;20:40-5. 
15. Tao C, Yan W, Li Y, Lu X. Effect of antidepressants on spatial memory deficit induced by dizocilpine. Psychiatry Res. 2016;244:266-72.

16. Freund TF, Katona I. Perisomatic inhibition. Neuron. 2007:56(1):33-42.

17. Klausberger T, Somogyi P. Neuronal diversity and temporal dynamics: the unity of hippocampal circuit operations. Science. 2008;321(5885):53-7.

18. Luoni A, Gass P, Brambilla P, Ruggeri M, Riva MA, Inta D. Altered expression of schizophrenia-related genes in mice lacking mGlu5 receptors. Eur Arch Psychiatry Clin Neurosci. 2018;268(1):77-87.

19. Lipina T, Weiss K, Roder J. The ampakine CX546 restores the prepulse inhibition and latent inhibition deficits in mGluR5-deficient mice. Neuropsychopharmacology. 2007;32(4):745-56.

20. Barnes SA, Pinto-Duarte A, Kappe A, Zembrzycki A, Metzler A, Mukamel EA, et al. Disruption of mGluR5 in parvalbumin-positive interneurons induces core features of neurodevelopmental disorders. Mol Psychiatry. 2015;20(10):1161-72.

21. Mascio G, Bucci D, Notartomaso S, Liberatore F, Antenucci N, Scarselli $P$, et al. Perineuronal nets are under the control of type-5 metabotropic glutamate receptors in the developing somatosensory cortex. Transl Psychiatry. 2021;11(1):109.

22. Homayoun H, Moghaddam B. NMDA receptor hypofunction produces opposite effects on prefrontal cortex interneurons and pyramidal neurons. J Neurosci. 2007;27(43):11496-500.

23. Moghaddam B, Javitt D. From revolution to evolution: the glutamate hypothesis of schizophrenia and its implication for treatment. Neuropsychopharmacology. 2012;37(1):4-15.

24. Carlén M, Meletis K, Siegle JH, Cardin JA, Futai K, Vierling-Claassen $D$, et al. A critical role for NMDA receptors in parvalbumin interneurons for gamma rhythm induction and behavior. Mol Psychiatry. 2012:17(5):537-48.

25. Rosenthal-Simons A, Durrant AR, Heresco-Levy U. Autoimmune-induced glutamatergic receptor dysfunctions: conceptual and psychiatric practice implications. Eur Neuropsychopharmacol. 2013;23(12):1659-71.

26. Tu JC, Xiao B, Naisbitt S, Yuan JP, Petralia RS, Brakeman P, et al. Coupling of mGluR/Homer and PSD-95 complexes by the Shank family of postsynaptic density proteins. Neuron. 1999;23(3):583-92.

27. Doherty AJ, Palmer MJ, Henley JM, Collingridge GL, Jane DE. (RS)2-chloro-5-hydroxyphenylglycine (CHPG) activates mGlu5, but no mGlu1, receptors expressed in $\mathrm{CHO}$ cells and potentiates NMDA responses in the hippocampus. Neuropharmacology. 1997;36(2):265-7.

28. Ugolini A, Corsi M, Bordi F. Potentiation of NMDA and AMPA responses by group I mGluR in spinal cord motoneurons. Neuropharmacology. 1997;36(8):1047-55.

29. Awad H, Hubert GW, Smith Y, Levey Al, Conn PJ. Activation of metabotropic glutamate receptor 5 has direct excitatory effects and potentiates NMDA receptor currents in neurons of the subthalamic nucleus. J Neurosci. 2000;20(21):7871-9.

30. Attucci S, Carlà V, Mannaioni G, Moroni F. Activation of type 5 metabotropic glutamate receptors enhances NMDA responses in mice cortical wedges. Br J Pharmacol. 2001;132(4):799-806.

31. Mannaioni G, Marino MJ, Valenti O, Traynelis SF, Conn PJ. Metabotropic glutamate receptors 1 and 5 differentially regulate CA1 pyramidal cell function. J Neurosci. 2001;21(16):5925-34.
32. Pisani A, Gubellini P, Bonsi P, Conquet F, Picconi B, Centonze D, et al. Metabotropic glutamate receptor 5 mediates the potentiation of $\mathrm{N}$-methyl-D-aspartate responses in medium spiny striatal neurons. Neuroscience. 2001;106(3):579-87.

33. Moutin E, Raynaud F, Roger J, Pellegrino E, Homburger V, Bertaso F, et al. Dynamic remodeling of scaffold interactions in dendritic spines controls synaptic excitability. J Cell Biol. 2012;198(2):251-63.

34. Lu YM, Jia Z, Janus C, Henderson JT, Gerlai R, Wojtowicz JM, Roder JC. Mice lacking metabotropic glutamate receptor 5 show impaired learning and reduced CA1 long-term potentiation (LTP) but normal CA3 LTP. J Neurosci. 1997;17(13):5196-205.

35. Imbriglio T, Verhaeghe R, Martinello K, Pascarelli MT, Chece G, Bucci $D$, et al. Developmental abnormalities in cortical GABAergic system in mice lacking mGlu3 metabotropic glutamate receptors. FASEB J. 2019;33(12):14204-20.

36. Tremblay R, Lee S, Rudy B. GABAergic interneurons in the neocortex: from cellular properties to circuits. Neuron. 2016;91(2):260-92.

37. van der Staay FJ, Rutten K, Erb C, Blokland A. Effects of the cognition impairer MK-801 on learning and memory in mice and rats. Behav Brain Res. 2011;220(1):215-29.

38. Salussolia CL, Prodromou ML, Borker P, Wollmuth LP. Arrangement of subunits in functional NMDA receptors. J Neurosci. 2011;31(31):11295-304.

39. Paoletti P, Bellone C, Zhou Q. NMDA receptor subunit diversity: impact on receptor properties, synaptic plasticity and disease. Nat Rev Neurosci. 2013;14(6):383-400.

40. Dumas TC. Developmental regulation of cognitive abilities: modified composition of a molecular switch turns on associative learning. Prog Neurobiol. 2005;76(3):189-211.

41. Matta JA, Ashby MC, Sanz-Clemente A, Roche KW, Isaac JT. mGluR5 and NMDA receptors drive the experience- and activity-dependent NMDA receptor NR2B to NR2A subunit switch. Neuron. 2011;70(2):339-51.

42. Ravikrishnan A, Gandhi PJ, Shelkar GP, Liu J, Pavuluri R, Dravid SM. Regionspecific expression of NMDA receptor GluN2C subunit in parvalbuminpositive neurons and astrocytes: analysis of GluN2C expression using a novel reporter model. Neuroscience. 2018;380:49-62.

43. Kinney JW, Davis CN, Tabarean I, Conti B, Bartfai T, Behrens MM. A specific role for NR2A-containing NMDA receptors in the maintenance of parvalbumin and GAD67 immunoreactivity in cultured interneurons. J Neurosci. 2006;26(5):1604-15.

44. Morris BJ, Cochran SM, Pratt JA. PCP: from pharmacology to modelling schizophrenia. Curr Opin Pharmacol. 2005;5(1):101-6.

45. Castagné $\mathrm{V}$, Moser PC, Porsolt RD. Preclinical behavioral models for predicting antipsychotic activity. Adv Pharmacol. 2009;57:381-418.

46. Ulivieri M, Wierońska JM, Lionetto L, Martinello K, Cieslik P, Chocyk A, et al. The trace kynurenine, cinnabarinic acid, displays potent antipsychoticlike activity in mice and its levels are reduced in the prefrontal cortex of individuals affected by schizophrenia. Schizophr Bull. 2020;46(6):1471-81.

\section{Publisher's Note}

Springer Nature remains neutral with regard to jurisdictional claims in published maps and institutional affiliations. 